\title{
Role of reservoir construction in regional land use change in Pengxi River basin upstream of the Three Gorges Reservoir in China
}

\author{
Li-Jing Wang ${ }^{1} \cdot \mathrm{Li} \mathrm{Wu}{ }^{2} \cdot \mathrm{Xi}$-Yong $\mathrm{Hou}^{2} \cdot$ Bing-Hui Zheng ${ }^{1} \cdot \mathrm{Hong} \mathrm{Li}^{1} \cdot$ \\ Stefan Norra ${ }^{3}$
}

Received: 12 October 2015/Accepted: 18 May 2016/Published online: 24 June 2016

(C) Springer-Verlag Berlin Heidelberg 2016

\begin{abstract}
The impact of the Three Gorges Reservoir (TGR) construction on land use change has attracted worldwide concern. However, quantitative evidence is lacking for the drivers of land use change resulting from the TGR during and after construction. We used the Pengxi River basin, located upstream of the Three Gorges dam, to evaluate the effects of large-scale hydrological engineering on land use. Landsat remote sensing images from 1995, 2000, 2005 and 2010 covering the main construction period of the TGR were obtained. The largest changes were the conversion of land to water bodies and built-up areas, corresponding to reservoir impoundment and population resettlement during TGR construction. These changes were more intensive downstream of the TGR and closer to the river. Compared with 2000-2005, the expansion in water bodies during 2005-2010 moved from lower to higher elevations. The distribution of built-up land during the two periods was similar, mainly because the planned resettlement zones were fixed and spatially concentrated. Geographical and environmental factors, such as elevation, slope, location, soil type and precipitation, still controlled
\end{abstract}

This article is part of a Topical Collection in Environmental Earth Sciences on "Environmental Research of the Three Gorges

Reservoir", guest edited by Binghui Zheng, Shengrui Wang, Yanwen Qin, Stefan Norra, and Xiafu Liu.

Bing-Hui Zheng

zhengbinghui@craes.org.cn

1 State Environmental Protection Key Laboratory of Drinking Water Source Protection, Chinese Research Academy of Environmental Sciences (CRAES), Beijing 100012, China

2 Yantai Institute of Costal Zone Research, Chinese Academy of Sciences, Yantai 264003, China

3 Institute of Geography and Geoecology, Karlsruhe Institute of Technology, 76131 Karlsruhe, Germany land use patterns. Land use pattern in 2020 under two scenarios was simulated using a multi-criteria evaluation cellular automata-Markov model. Scenario 2 was more realistic and helpful for management decisions. The scenarios highlighted the indirect influences of TGR construction on land use change after 2010. Indirect driving forces were mainly reflected through related policies or plans, especially from the perspective of water conservation in the newly built reservoir.

Keywords Land use change $\cdot$ Scenario simulation $\cdot$ Dam reservoir construction - Pengxi River - Three Gorges Reservoir $\cdot$ MCE-CA-Markov model

\section{Introduction}

The impacts of large reservoir construction on ecosystems are complex and profound and raise a number of important scientific issues (Nilsson et al. 2005; Stone 2008). As one of the world's biggest dam reservoirs, the Three Gorges Reservoir (TGR) has attracted worldwide academic debate regarding its positive and negative effects since the start of Three Gorges project in the 1990s (Shen and Xie 2004; Stone 2011; Zhang and Lou 2011; Morgan et al. 2012; Peng et al. 2014). In the hierarchy of TGR impacts, water quality has been promoted as the primary concern that is directly associated with the physical, chemical and biological consequences of dams and reservoir operation (Tullos 2009; Bergmann et al. 2012). Many studies have been performed to assess the impact of the TGR in changing the water environment especially in upstream areas (Holbach et al. 2013; Wang et al. 2014a; Zhao et al. 2015). The water environment has been linked to land use patterns as a result of strong relationships between land use and nutrient export 
in waters (Osborne and Wiley 1988; Ahearn et al. 2005; Shen et al. 2013). Therefore, it is necessary to assess the regional land use changes to better understand of the impact of the TGR on the water environment.

Land use change can significantly impact the earth's ecosystem functions including climate, soil erosion, surface runoff, landscape degradation and nutrient fluxes (Wang et al. 2012; Austin et al. 2013; Comarazamy et al. 2013; Schönbrodt-Stitt et al. 2013a, b; Wang et al. 2014b; Strehmel et al. 2015). Regional land use change under the influence of a large dam reservoir construction is of particular interest especially in the TGR area, as shown by an increasing trend of published literature from 2001 to 2013 (Jiang et al. 2016). Tremendous modifications to land use can result from reservoir construction projects due to reservoir impoundment, population migration and resettlement, and the reconstruction of counties and towns (Jackson and Sleigh 2000; Li et al. 2001; Tullos 2009; Seeber et al. 2010; Zhao et al. 2013). Previous studies have provided evidence of the change in land use in the TGR area since the 1970s (He et al. 2003; Sun et al. 2003; Huang et al. 2006; Xu et al. 2007; Zhang et al. 2007; Shao et al. 2008; Li et al. 2015). Land use change after 2000 has been characterized by the increase in water and built-up areas at the expense of farmland, forests and grassland (Zhang et al. 2009; Cao et al. 2011; Li et al. 2015). The role of TGR construction in land use conversion has also been noted and discussed (Zhang et al. 2007; Cui et al. 2012; Shao et al. 2013).

However, previous studies have not addressed all the questions, including: (1) The TGR project was planned in stages with specific construction phases in different periods. The phases of the TGR project and spatiotemporal changes of land use are seldom correlated to reveal the processes of reservoir impacts. Detailed quantitative evidence showing the driving mechanisms of TGR impacts is still lacking. (2) Compared with human disturbances such as TGR construction, the influence of traditional driving factors, especially natural geographical elements, on the land use has been overlooked in the TGR area in the past decades. (3) The indirect impacts of the reservoir after the completion of construction are often underestimated (Orr et al. 2012; Fearnside 2015). This type of impact is usually coupled with a socioeconomic development plan and management policies but originates from dam reservoir construction. This is also the case in the TGR area. Correspondingly, the direction and intensity of future land use changes are rarely discussed, and land use predictions for the time after the completion of TGR project are inadequate ( $\mathrm{Li}$ et al. 2010).

In this study, we selected the Pengxi River basin upstream of the TGR as the study area to: (1) enrich the knowledge of land use dynamics at a sub-basin scale in the TGR area, focusing on the Pengxi River basin, which is less studied than other sub-basins such as the Xiangxi River basin; (2) measure the influence of TGR construction in land use change during and after its construction with quantitative evidence, especially spatial distribution of dominant land use changes at small catchment scales before 2010 and comparisons of scenario simulation results in 2020; and (3) understand the influence of typical geographical and environmental factors on land use, especially against the background of TGR construction.

\section{Materials and methods}

\section{Study area}

The Three Gorges Reservoir, with a capacity of $3.93 \times 10^{10} \mathrm{~m}^{3}$ and a water catchment area of $5.79 \times 10^{4} \mathrm{~km}^{2}$, is located in the upper waters of the Yangtze River in China (Fig. 1). The water surface area is $1084 \mathrm{~km}^{2}$ at a water level of $175 \mathrm{~m}$ a.s.l. at the dam. The water level changes seasonally between $145 \mathrm{~m}$ a.s.l. and $175 \mathrm{~m}$ a.s.l. due to water level variations associated with reservoir operation, producing a fluctuation zone with an area about $348 \mathrm{~km}^{2}$. The TGR was systematically engineered to integrate the functions of flood control, power generation, shipping and water supply. The construction project was planned in stages including the dam building project (water conservancy hub and power transmission project), reservoir impoundment project and population resettlement project. The project started in 1994, but the first reservoir impoundment did not occur until 2003. The Pengxi River basin is a typical mid-scale tributary of the TGR located between $107^{\circ} 44^{\prime} 50^{\prime \prime} \mathrm{E}-108^{\circ} 53^{\prime} 56^{\prime \prime} \mathrm{E}$, $30^{\circ} 39^{\prime} 35^{\prime \prime} \mathrm{N}-31^{\circ} 41^{\prime} 19^{\prime \prime} \mathrm{N}$. The watershed area is $5172.5 \mathrm{~km}^{2}$ mainly covering Kai County and Yunyang County, administrated from Chongqing city. As one of over 40 major first-order tributaries of the TGR, the Pengxi River basin has the largest resettled population in the TGR region $(11 \%)$, the largest area flooded $(15.5 \%)$ and the largest area of fluctuation (15.9\%) (EOTGPCC 2011). A map of the Pengxi River basin is shown in Fig. 1. The time line of the TGR project is shown in Fig. 2.

\section{Land use analysis}

The land use map of the Pengxi River basin was interpreted from 1995, 2000, 2005 and 2010s Landsat TM and +ETM images. A supervised classification was performed using imaging software package ERDAS IMAGINE 9.1 (Hexagon Geospatial, Norcross, GA, USA). Human-computer interactive on-screen visual interpretation techniques were used to ensure the mapping accuracy because of the complexity of geographical features in the basin and the errors 


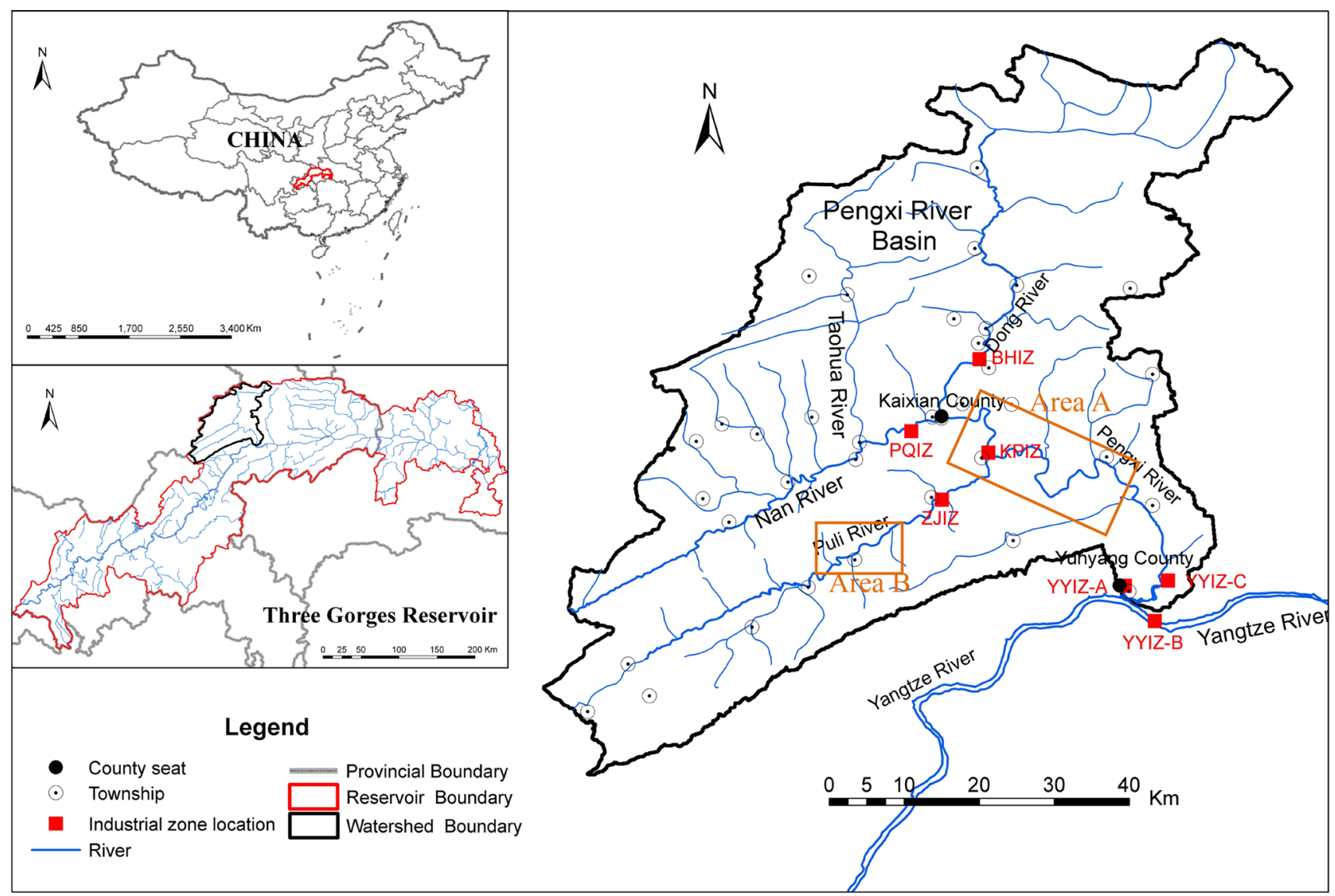

Fig. 1 Map of the Pengxi River basin (area A and area B are the typical areas for simulation results comparison)

Fig. 2 Construction time line of Three Gorges Reservoir project

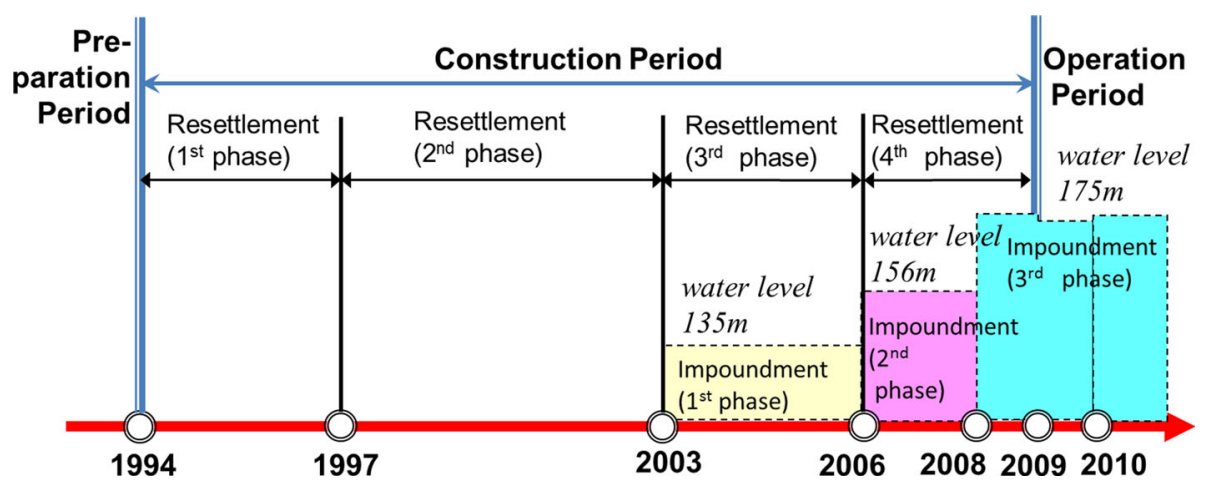

from automatic interpretation using traditional unsupervised classification methods (Liu et al. 2005). During the interpretation, the smallest mapping unit for ground objects was adopted as 2-3 pixels on Landsat images. The interpretation results were stored as a coverage file in ArcGIS software (ESRI, Inc., Redlands, CA, USA). The land use classification system, developed by the Chinese Academy of Sciences and used for building national land use databases at a spatial scale of 1:100,000, was applied to this study. The land use was classified into six categories: (1) farmland, including paddy field and dry farming land; (2) forest land, including forest, shrub and woods; (3) grassland, including different coverage types; (4) water body, including rivers, lakes and reservoirs; (5) built-up land, including city and rural settlements; and (6) unused land, including bare soil and bare rocks and wetland (see Table 1). The detailed definition of each class can be found in the literature published by Liu et al. (2005). A Shuttle Radar Topography Mission digital elevation model (SRTM DEM) from the United States Geological Survey with a spatial resolution of $90 \mathrm{~m} \times 90 \mathrm{~m}$ was obtained to assist with land use mapping. 
Table 1 The classification system of land use in the Pengxi River basin

\begin{tabular}{|c|c|c|c|}
\hline \multicolumn{2}{|c|}{ Level 1} & \multicolumn{2}{|c|}{ Level 2} \\
\hline Code & Name & Code & Name \\
\hline \multirow[t]{2}{*}{1} & Farmland & 11 & Paddy field \\
\hline & & 12 & Dry farming land \\
\hline \multirow[t]{4}{*}{2} & Forest land & 21 & Forest \\
\hline & & 22 & Shrub \\
\hline & & 23 & Woods \\
\hline & & 24 & Others \\
\hline \multirow[t]{3}{*}{3} & Grassland & 31 & Dense grass \\
\hline & & 32 & Moderate grass \\
\hline & & 33 & Sparse grass \\
\hline \multirow[t]{6}{*}{4} & Water body & 41 & Rivers \\
\hline & & 42 & Lakes \\
\hline & & 43 & Reservoir and ponds \\
\hline & & 44 & Permanent ice and snow \\
\hline & & 45 & Beach and shore \\
\hline & & 46 & Bottomland \\
\hline \multirow[t]{3}{*}{5} & Man-made built-up land & 51 & City \\
\hline & & 52 & Rural settlements \\
\hline & & 53 & Others \\
\hline \multirow[t]{7}{*}{6} & Unused land & 61 & Sand \\
\hline & & 62 & Gobi \\
\hline & & 63 & Salina \\
\hline & & 64 & Wetland \\
\hline & & 65 & Bare soil \\
\hline & & 66 & Bare rock \\
\hline & & 67 & Others \\
\hline
\end{tabular}

The definition of each land use class can be found in the literature published by Liu et al. (2005)

Land use dynamic indices were calculated to describe the rate of land use change. It consisted of the index $K$ referring to the change rate of single land use type and integrated index $L C$ addressing the change rate of regional land use over a certain period of time in a certain study area. The equations are as follows (Xiao et al. 2006; Zhu and Li 2003):

$K=\frac{U_{b}-U_{a}}{U_{a}} \times \frac{1}{T} \times 100 \%$

$L C=\left(\sum_{i=1}^{n} \Delta L U_{i-j} / 2 \sum_{i=1}^{n} L U_{i}\right) \cdot \frac{1}{T} \times 100 \%$

where $U_{a}$ and $U_{b}$ represent the area of a certain land use type at the beginning and end of the observation period, respectively; $L U_{i}$ is the area of the $i$ th type land use at the beginning of observation period; $\Delta L U_{i-j}$ presents the area of the $i$ th type of land use transfer to the other land use type in the observation period; and $T$ refers to the duration of the observation period.

\section{Coupled MCE-CA-Markov model}

A Markov model is a method to predict event occurrence probability (Bell 1974; Sarwar 1986; Mahmoud and Alazba 2015). The Markov process moves randomly from one state to another at each time step with no carryover properties, and it is appropriate for simulating changes in land use structure. Cellular automata (CA) is a dynamic model with the ability to calculate time and space, when time, space and states are discrete (Barredo et al. 2003; Al-Ahmadi et al. 2009; Sang et al. 2011). The CA-Markov model combines CA's spatial simulation ability for a complex system with the Markov model's advantage of long-term predictions, and has been widely used in land use studies (Guan et al. 2011; Kamusoko et al. 2009; Zhang et al. 2011; Mondal and Southworth 2010). In the CA-Markov model, the Markov model supports the quantitative prediction of land use change, but without spatial features; the CA model controls the spatial dynamics among the land use types dependent upon neighborhoods and transition rules. Multi-criteria evaluation (MCE) is a general evaluation method for processing many attributes (Gómez-Delgado and Tarantola 2007; Nguyen et al. 2015). Its main objective is to combine a set of criteria into a compromise proposal for a decision according to a specific objective. In this study, the MCE method was selected to develop suitability maps of each land use type and to construct transition rules for CA. The simulation used IDRISI software (IDRISI Andes V15.0), which was developed by experts at Clark University's Clark Labs.

\section{Markov model}

The most significant characteristic of the Markov process is that the state at time $t+1$ only relates to the state at time $t$, not to previous states. Therefore, land use change can be expressed as

$S_{(t+1)}=P \cdot S_{(t)}$

where $S(t)$ and $S(t+1)$ are row vectors that show the land use distribution at time step $t$ and $t+1$, respectively. $P$ presents the transition probability matrix which can be calculated by overlapping land use maps at time $t$ with $t+1 . P$ is expressed as

$$
\begin{aligned}
& P=\left(\begin{array}{cccc}
P_{11} & P_{12} & \ldots & P_{1 j} \\
P_{21} & P_{22} & \ldots & P_{2 j} \\
\ldots & \ldots & \ldots & \ldots \\
P_{i 1} & P_{i 2} & \ldots & P_{i j}
\end{array}\right) \quad 0 \leq P_{\mathrm{ij}} \leq 1 \\
& \text { and } \sum_{j=1}^{n} P_{\mathrm{ij}}=1(i, j=1,2,3, \ldots, n)
\end{aligned}
$$


where $n$ is the number of land use types and $P_{i j}$ is the transition probability of the $i$ th type land use into the $j$ th type land use

\section{Cellular automata model}

CA consists of cells, cellular space, neighborhoods and rules. This can be expressed as (Sang et al. 2011):

$S(t+1)=f(S(t), N)$

where $S$ is the finite and discrete states set; $N$ is the neighborhood of cellular space; $t$ and $t+1$ refer to different times, respectively, and $f$ represents the transformation rules of the cellular states in local space. In this study, based on the knowledge acquired during field investigations, the computation load of the model, and the scale features for characterizing spatial variation, a $5 \times 5$ neighborhood was adopted.

\section{Multi-criteria evaluation}

Based on analysis of land use and a literature review, the evaluation factors of land suitability for each land use type were selected. These were entered into the MCE model and normalized in the range of 0 (the least suitable) to 255 (the most suitable). Factor weights are normally set through expert scoring. Using a weighted linear method to multiply the normalized factor value and weight, suitability map for each land use type was developed and entered into the CAMarkov model.

In the IDRISI software, the weighted linear combinations method is recommended for MCE to normalize the factors to continuous suitability values. Given that raster data are the supported format in IDRISI, land use maps of Pengxi River basin in vector format were first converted to raster maps with a grid size of $60 \mathrm{~m} \times 60 \mathrm{~m}$ (this grid size was adopted according to the precision levels of the land use maps mentioned above). To quantify the match between the simulation results and the actual image, the Kappa coefficient (Pontius 2000, 2002), a widely used index, was used to analyze simulation accuracy. Generally, $K>0.8$ means excellent results, $0.6-0.8$ equals good results, $0.4-0.6$ equals moderate results, $0.2-0.4$ equals poor results, and $0-0.2$ equates to very poor results.

In this study, based on the analysis in 3.2, slope, elevation, location (distance to the river and road), soil type and rainfall were selected as evaluation factors (see Table 2). Unused land was not included due to its uncertainty. The spatial data of traffic networks, including national, provincial, county and township roads in the Pengxi River basin, were extracted from the National Basic Geographical Information Database released by the National Administration of Surveying, Mapping and Geoinformation. The data of river system (five stage water system) and soil type at a spatial scale of 1:100,000 were derived from the national database developed by the Chinese Academy of Sciences. The spatial data for precipitation were interpolated based on the monitoring sites and data from the data set of Chinese terrestrial climatic data released by the China Meteorological Administration. With the initial simulation time of 2005, the Kappa coefficient between the observed 2010 and simulated 2010 land use maps was 0.97 , which indicated that the model can be applied to predict land use change. Using 2010 as the starting year of prediction, and setting the iteration number of CA model to 10, the land use patterns in 2020 were then simulated.

\section{Scenario analysis}

In this study, two scenarios were designed and applied. Scenario 1 was based on the land development trends from 2005 to 2010. The result under this scenario was basically the original predicted trajectory driven by past land use change characteristics. Scenario 2 was a manual intervention scenario where the transition rules for $\mathrm{CA}$, constructed

Table 2 Evaluation factors of land use change in the Pengxi River basin for the MCE-CA-Markov model

\begin{tabular}{|c|c|c|c|c|c|c|}
\hline \multirow[t]{2}{*}{ Land use type } & \multicolumn{6}{|c|}{ Evaluation factors } \\
\hline & Dis_river (m) & Dis_road (m) & Elevation (m) & Slope $\left(^{\circ}\right)$ & Soil type & Precipitation $(\mathrm{mm})$ \\
\hline Paddy field & + & + & + & + & + & \\
\hline Dry farming & + & + & + & + & + & \\
\hline Forest land & + & & + & + & + & \\
\hline Grassland & & & + & + & + & + \\
\hline Water body & + & & + & + & & + \\
\hline Built-up land & + & + & + & + & & \\
\hline
\end{tabular}

'+' means the factor of the column is selected. Dis_river and Dis_road indicate the vertical distance from the pixel to the nearest linear water system/road in Pengxi River basin which was derived using ArcGis software 
by MCE, were adjusted during the prediction process. This adjustment was performed according to the national policy and afforestation actions for prevention of soil erosion (Strehmel et al. 2015), national and regional TGR water protection and socioeconomic development plans for the future (CDRI 2009; EOTGPCC 2011; MEP 2012), and the near completion of the TGR construction project (Austin et al. 2013). Four constraints were considered in scenario 2, that is: (1) The trend of expansion to the water area caused by the reservoir impoundment should be terminated after 2010. (2) The fluctuation zone caused by TGR water level variation from 145 to $175 \mathrm{~m}$ a.s.l. during the year should be strictly protected from human interference. (3) Forest should be promoted to replace farmland on slopes above 25 degrees. (4) Industrial parks other than single industrial companies were encouraged to facilitate treatment of pollution. Built-up land should be planned around these locations. In the model, these constraints were addressed by the evaluation factors of MCE and were used to develop adjusted suitability maps for each land use type.

\section{Results and discussion}

\section{Land use changes from 1995 to 2010}

The land use changes from 1995 to 2010 in the Pengxi River basin are shown in Table 3 . The change rate of regional land use $(L C)$ was $0.17 \%$ from 1995 to 2000 , and then, it increased to $0.32 \%$ from 2000 to 2005 before falling to $0.11 \%$ between 2005 and 2010. As to the change rate of specific land use types $(K)$, the values of water bodies and built-up land were 0.64, 10.00, 10.35\% and 9.85, 5.91, 16.36\%, respectively, during 1995-2000, 2000-2005 and 2005-2010. The areas of water bodies and built-up land in 2010 were 2.35 and 3.52 times that in 1995, although their percentage levels were still low. Dry farming land and forest land were the main land use types, as both of their areas were above $30 \%$ over these periods. However, the change rate of dry farming land was quite different before and after 2000. It had a relatively high positive value $(K=0.6 \%)$ during 1995-2000 with $38.88 \mathrm{~km}^{2}$ converted from grassland, but had a relative low negative value in other periods.

Land use transition characteristics were further examined based on GIS overlap analysis during 2000-2010 (see Fig. 3). Nine land use classes, 11, 12, 03, 04, 21, 22, 23, 51 and 52 (see Table 1 for the land use code and classification), were considered in the analysis. Among the 72 nondiagonal elements in the transfer matrix where the land use transfer occurred, sorting by the number of transfer pixels, the first 18 types were selected as dominant land use change types accounting for 78.5-87.4\% of the total change areas. During 2000-2005, the first five transfer types were $12-23,12-03,03-12,12-22$ and 22-12, accounting for $53.8 \%$ of the total change areas of the first 18 types. This meant that mutual transfer between dry farming (12) and forest land $(22,23)$ or grassland (03) was most obvious. The transfers from other types to water area (04) and rural settlements (52) were also identified as dominant types in the ranking. During 2005-2010, the transfers from other types $(12,03,11)$ to water area $(04)$ and rural built-up land (52) fully covered the first five transfer types, namely 12-04, 03-04, 11-04, 11-52 and $03-52$, accounting for $51.6 \%$ of the total change area of the first 18 types.

Based on the above, during 1995-2000, land use change was characterized by a steady water area but increased dry farming land and built-up land. TGR construction was probably not the dominant driving factor in this period, especially considering reservoir impoundment had not yet started (see Fig. 2), and population resettlement had just started with relatively small planned number of about 48,000 people year ${ }^{-1}$ (Fu et al. 2013). Conventional driving factors (such as natural geographical elements and socioeconomic development) were the more important causal factors in this period (Shao et al. 2008). During 2000-2010, transfers from other land use types to water bodies and built-up land were identified as the dominant land use change types. The abnormal continuous extension of water area $(K>10 \%)$ implied that an unconventional disturbance or accidental event (such as TGR construction)
Table 3 Change of land use area from 1995 to 2010 in the Pengxi River basin

\begin{tabular}{|c|c|c|c|c|c|c|c|}
\hline \multirow[t]{2}{*}{ Land use type } & \multicolumn{4}{|c|}{ Area $\left(\mathrm{km}^{2}\right)$} & \multicolumn{3}{|c|}{ Land use dynamic index $K(\%)$} \\
\hline & 1995 & 2000 & 2005 & 2010 & $1995-2000$ & $2000-2005$ & 2005-2010 \\
\hline Paddy field & 643.97 & 640.31 & 627.35 & 619.15 & -0.11 & -0.41 & -0.26 \\
\hline Dry farming & 1469.08 & 1513.07 & 1502.65 & 1492.93 & 0.60 & -0.14 & -0.13 \\
\hline Forest land & 1561.33 & 1530.15 & 1542.69 & 1535.40 & -0.40 & 0.16 & -0.09 \\
\hline Grassland & 968.72 & 955.37 & 949.37 & 942.35 & -0.28 & -0.13 & -0.15 \\
\hline Water body & 26.82 & 27.68 & 41.52 & 63.01 & 0.64 & 10.00 & 10.35 \\
\hline Built-up land & 6.79 & 10.13 & 13.13 & 23.87 & 9.85 & 5.91 & 16.36 \\
\hline Unused Land & 1.27 & 1.27 & 1.27 & 1.27 & 0.00 & 0.00 & 0.00 \\
\hline
\end{tabular}


(a)

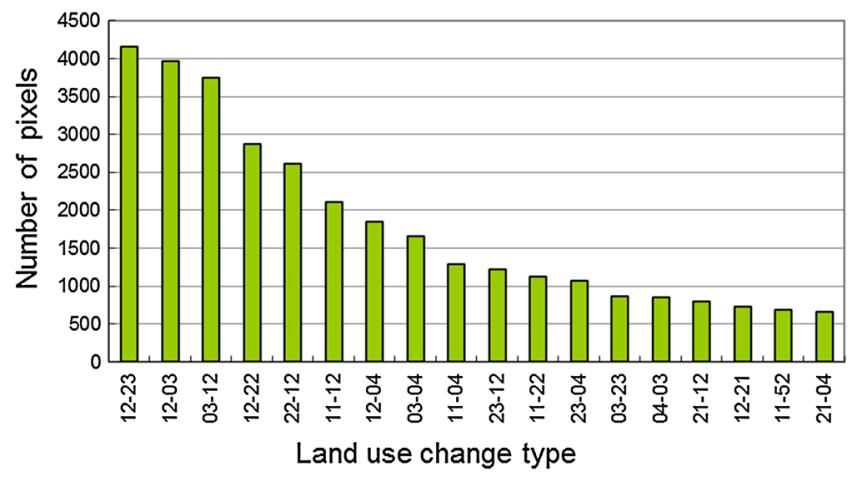

Fig. 3 Identification of dominant land use change types in the Pengxi River basin (the codes are as follows: 11-paddy field, 12-dry farming land, 03-grassland, 04-water body, 21-forest, 22-shrub,

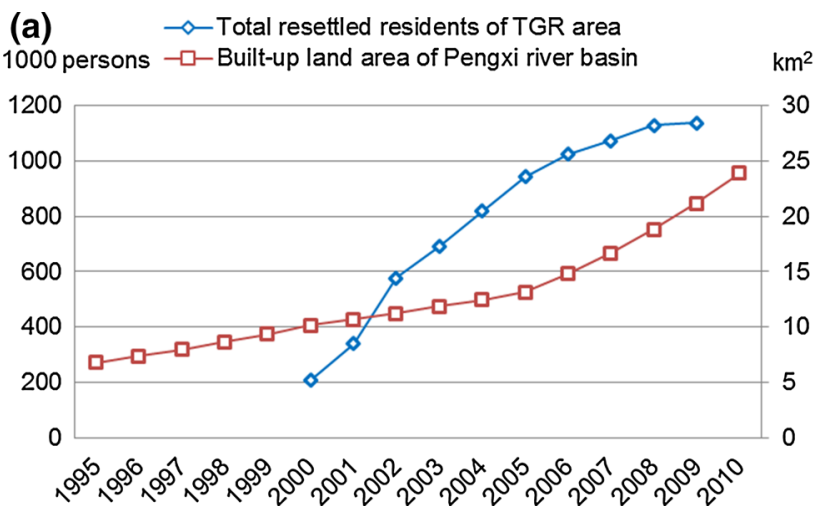

Fig. 4 Variation of TGR construction-related indicators and land use change in the Pengxi River basin (the statistical scope of total resettled residents contained the Chongqing part of TGR area. The

must have combined with conventional factors to dominate the driving forces of land use change. The reservoir experienced its first impoundment in 2003, its second impoundment in 2006 at the $156 \mathrm{~m}$ a.s.l. water level, and achieved the planned $175 \mathrm{~m}$ a.s.l. water level in 2010. The resettlement of 1.03 million people $(79.4 \%$ of planned population resettlement) was finished in this period (Fu et al. 2013). The conventional driving factors of land use change were dwarfed under these circumstances. This opinion was consistent with the research by Cui et al. (2012) and Shao et al. (2013).

\section{Land use changes in response to the construction of the TGR}

To confirm the relationship between land use change and the reservoir construction, the variation in some key indicators related to TGR construction and land use change is shown in Fig. 4 (Chongqing Bureau of Statistics 2012). The Pearson correlation coefficient for total resettlement (b)

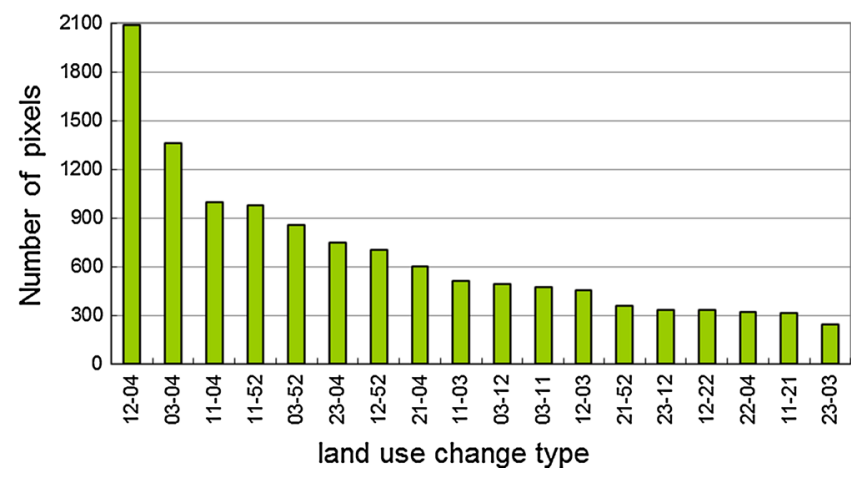

23-woods, 51-city and 52-rural settlements. '12-23' means the transfer from 12 to 23). a 2000-2005, b 2005-2010

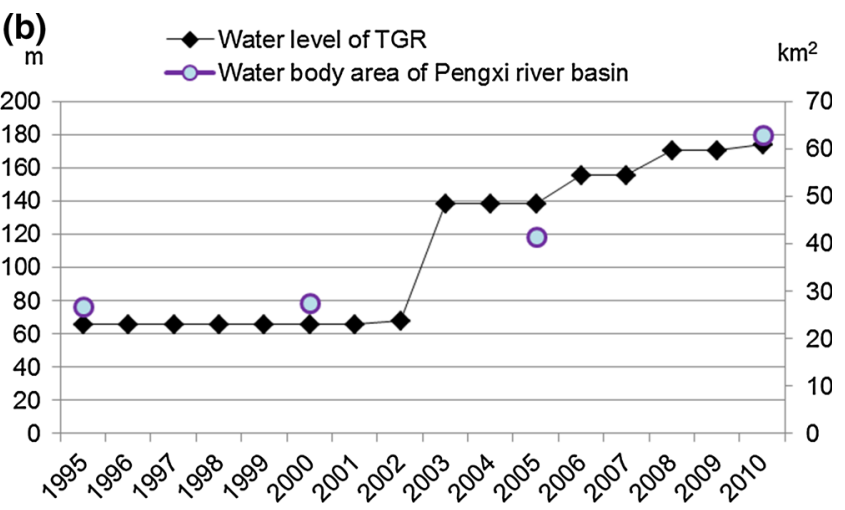

data on built-up land area were interpolated according to the annual increase rate during every 5-year period. The water level was measured on December 1 ever year)

people and built-up land area from 2000 to 2010 showed a positively significant correlation $(r=0.849, p<0.01)$ (Fig. 4a). The rapid expansion of the water body area in 2005 and 2010 (Fig. 4b) was consistent with the time of reservoir impoundment.

To further investigate the impact of the TGR on land use, the spatial distribution of dominant land use change types for water bodies and built-up land was analyzed for the different periods. Using small catchments as the statistical unit (Wang et al. 2014a), the total number of the pixels with a certain transfer type reflected the intensity of land use change (See Fig. 5).

The change in water area is more intensive downstream than upstream and also more intensive in the areas surrounding the river than in the areas far away from the river (Fig. 5a-c). Catchments 57, 60, 51 and 52 located closest to the river estuary with lowest terrain had the largest transfer areas (5032 pixels in total, $41.2 \%$ of all transfer areas in the basin), followed by catchments 31,38 and 40 (1245 pixels in total) located close to the upper reaches. 

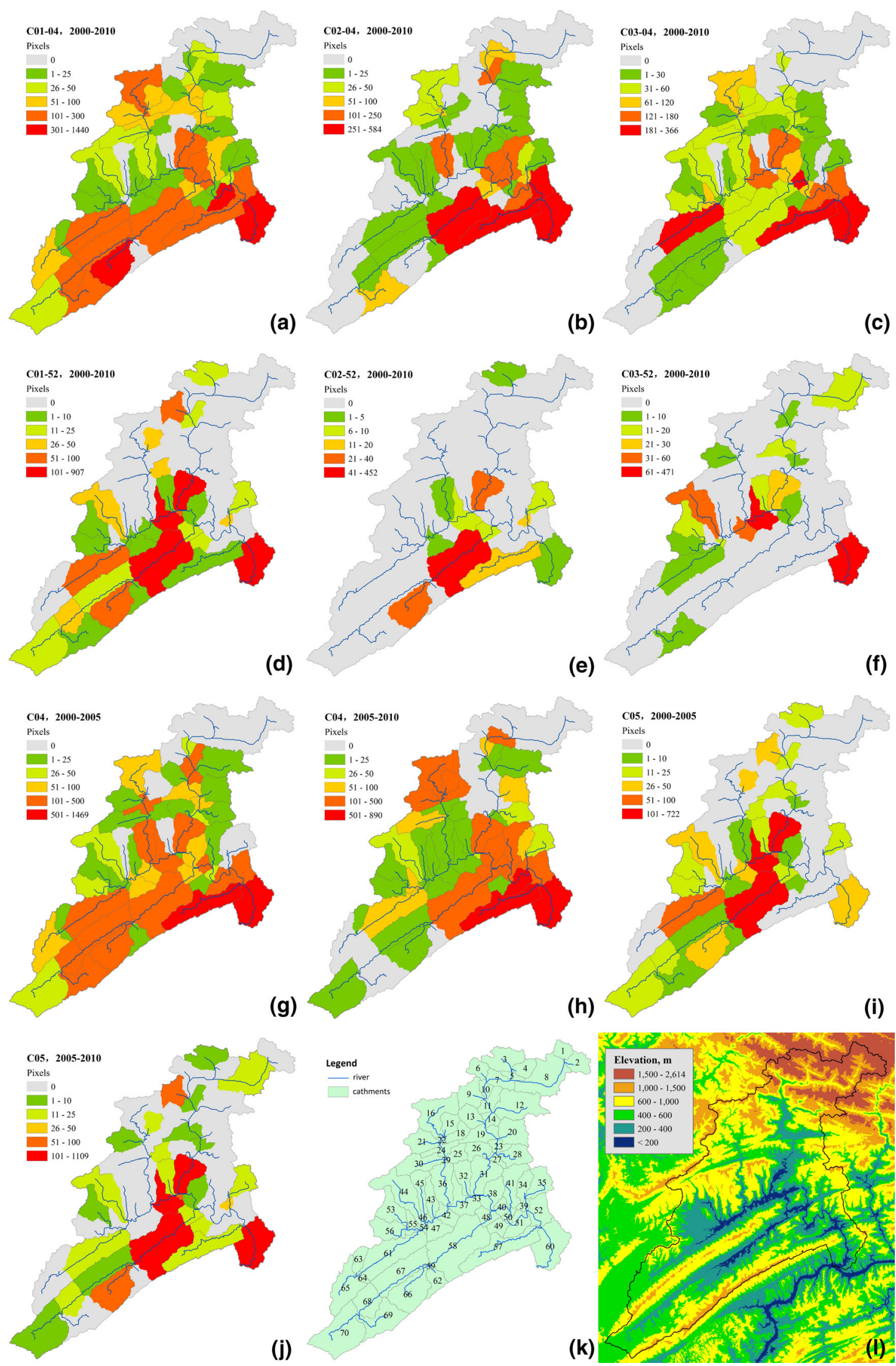
4Fig. 5 Spatial and temporal distribution of some dominant land use change types in the Pengxi River basin [the code is as follows: 01farmland, 02 - forest land, 03-grassland, 04-water body and 05built-up land. C01-04 means the land use change from 01 to 04 , and C04 means the land use change from all other land use types to 04 . The division of catchments in $\mathbf{k}$ amended based on the literature published by Wang et al. (2014a)]

Reservoir impoundment raises the water level and causes water intrusion from the main river into the tributary, pushing water back along the tributary and flooding land downstream or close to the river first and land that is upstream or far from the river second. The observed spatial distribution of water area expansion in the Pengxi River basin matches this process of reservoir impoundment. Over time, the extension of the water area shows a trend of extending from low elevation regions to high elevation regions (Fig. 5g, h, 1). For example, in the small tributary of the Dong River, land use change was most intensive in two catchments (11 and 14) during 2000-2005. The water area extension in other two catchments (7 and 10) located in the upstream area was most intensive during 2005-2010. The same pattern was found in the small tributary of the Taohua River. A 30-m uplift in water level from $145 \mathrm{~m}$ a.s.1. to $175 \mathrm{~m}$ a.s.1. happened during 2005-2010, which further expanded the influence zone of reservoir impoundment. The observed temporal change of the water area extension reflects the characteristics of staged flood activity of the TGR construction and the pattern of impact.

The change in built-up areas was found to be closely related to reservoir construction, especially in the middle and lower reaches of the basin, and close to the water body. This feature is more prominent in the transformation of farmland-rural settlements (01-52) and forest land-rural settlements (02-52) (see Fig. 5d, e). The Three Gorges project produced reservoir resettlements of 1.29 million people, only $15.1 \%$ of whom were moved outside the reservoir area, with the majority resettled locally (Fu et al. 2013; Austin et al. 2013). Rural residents were encouraged to build houses above the original flooded location, which implies that a catchment with more flooded water areas would have relatively more resettled built-up land area. The observed spatial distribution of rural settlements was consistent with the spatial pattern of submerged land and resettlement policy in the process of reservoir construction. Regarding the temporal change of built-up land area, the spatial distribution of expansion in 2000-2005 and 2005-2010 was basically consistent, which was different from water area expansion (Fig. 5i, j). For example, catchments 31,37 and 58 had the most intensive change in both periods, followed by catchments 9, 60 and 66 . We also found catchments with intensive land use transfer were mainly distributed around the location of existing towns, for three reasons. First, the resettlement work was basically equivalent in 2000-2005 (averaged 109,000 people year $^{-1}$ ) and 2005-2010 (averaged 96,500 people year ${ }^{-1}$ ) (Fu et al. 2013). Second, the planned resettlement locations were relatively fixed, which prevented free expansion, and tended to be distributed in neighboring villages and towns. Finally, the population in the resettlement places was more concentrated, and thus, the inundated area of built-up land did not produce the equivalent new area of built-up land.

\section{Influence of geographical features on the TGR's role in land use change}

The relatively stable geographical and environmental factors, including topography (elevation, slope), location (distance to the river, distance to the road) and ecological elements (soil type, the average rainfall over the years), were usually the controlling factors of regional land use pattern. However, they were also important factors that affected the impact of the TGR on regional land use change (see Fig. 6).

It was found that there was a relationship between the distribution of land use and the change of landform. Paddy fields, forest land, water body and built-up land were obviously affected by topography (see Fig. 6a, b). As the elevation increased, the proportion of paddy field was reduced, accounting for $23.06 \%$ in the area below 200-m elevation and $<1 \%$ in the area above an elevation of $1500 \mathrm{~m}$. Similarly, water and built-up land accounted for 18.41 and $7.61 \%$ in the area below $200 \mathrm{~m}$ elevation, but $<1 \%$ in the area above $400 \mathrm{~m}$. In contrast, the proportion of forest land rose with an increase in elevation, occupying only $14.64 \%$ of the area below 200-m elevation but occupying $52.94 \%$ of the region above $1500 \mathrm{~m}$. The proportion of dry land and grassland under different conditions was relatively stable. The relationship between slope and the land use distribution was similar to elevation. It was also noticed that most of the water and built-up land was distributed in the region below $200 \mathrm{~m}$ and $<15^{\circ}$. This explained why these two land use types were more susceptible to the impact of TGR impoundment, compared with other land use types.

The influence of locational difference, such as the distance to the river and road, on water area and built-up area was the most significant (see Fig. 6c, d). The area close to the river (distance $<1000 \mathrm{~m}$ ) formed only $18.49 \%$ of the total basin area, but the distribution of water bodies (89.5\% of the total water area in the basin) and built-up land (77.3\% of the total built-up land area in the basin) was highly concentrated in this area. Therefore, the influence of water intrusion caused by TGR construction was reflected most significantly by the change in these two land use types. Similarly, the area close to the road 



(c)

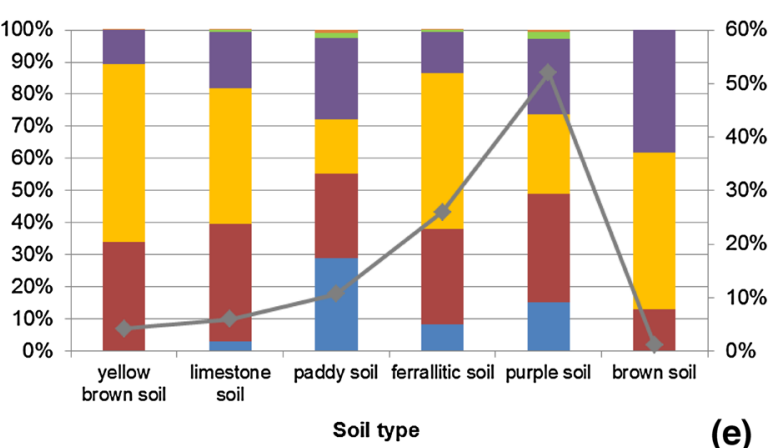

Fig. 6 Relationship between natural geographical elements and land use distribution in the Pengxi River basin (the area proportion of a certain land use type under analysis is shown on the principal axis.

(distance $<1000 \mathrm{~m}$ ) formed only $34.76 \%$ of the total basin area, but $91.03 \%$ of the total built-up land area of the basin was concentrated close to roads. Due to this distribution, the newly developed built-up area for population resettlement caused by TGR construction focused on places with existing road networks including counties, towns and villages. However, compared with other land use types, the proportion of water and built-up land was still small, respectively, 6.56 and $2.13 \%$ in the above two regions.

Other ecological factors, such as soil and precipitation, were also closely related to the distribution of land use (see Fig. 6e, f). The land use on all kinds of soil was dominated by forest land, dry faming land and grassland. Paddy fields, a land use type closely related to human activities, were mainly distributed in purple soil and paddy soil areas with the proportion of 15.08 and $29.02 \%$, but its proportion was
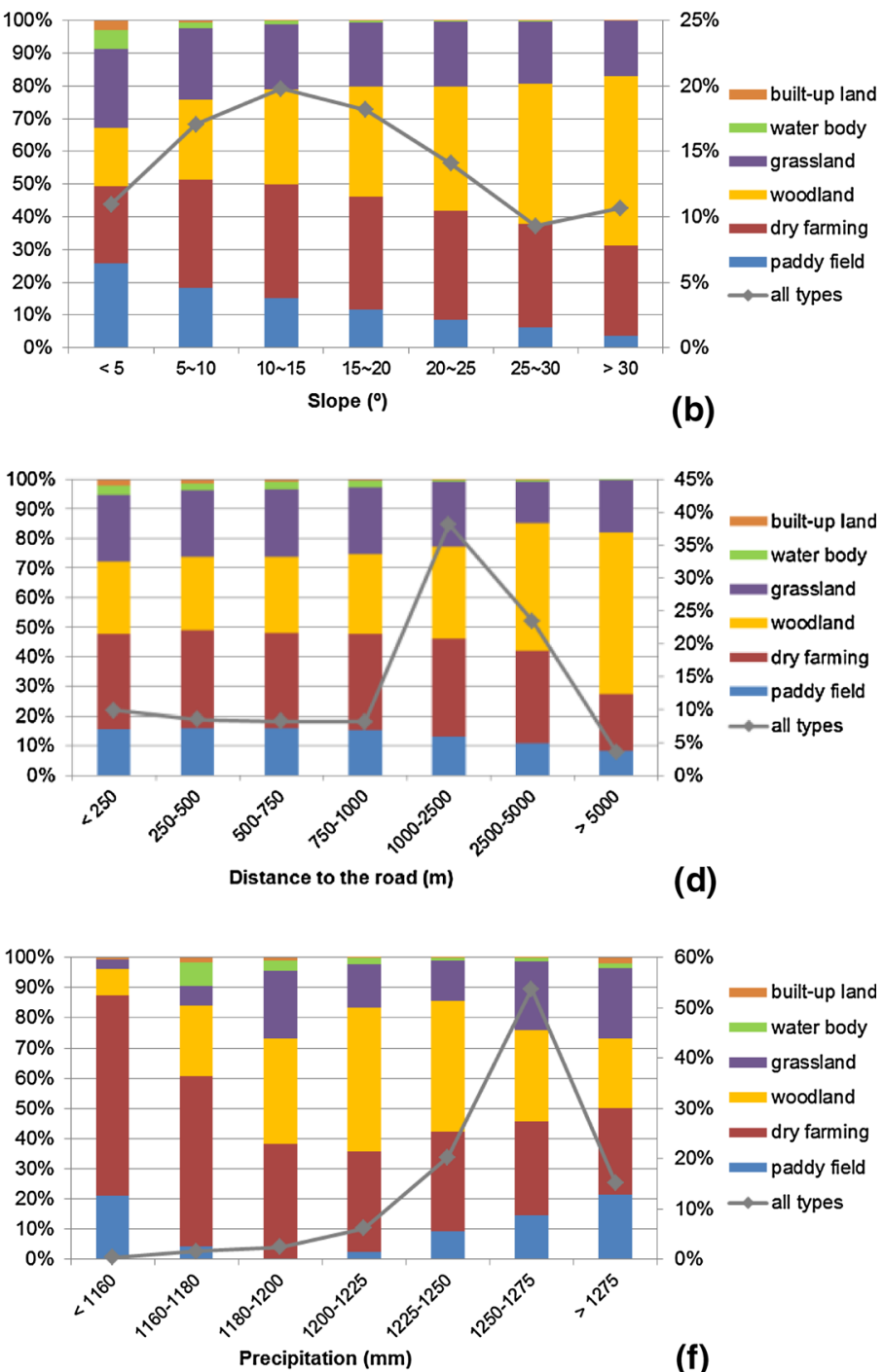

The proportion of all land area under analysis compared with the total area of the basin is shown on the secondary axis. The 2010 land use map used for the analysis)

only $0-8.17 \%$ in other regions. Land use types with relatively minor human disturbance, such as forest, were mainly distributed in yellow brown soil, brown soil, lime soil and ferralitic soil regions, accounting for 42.44-55.31\% of the total area of each soil type. The spatial difference in precipitation in the study area was not significant with a variation of $1151-1305 \mathrm{~mm}$, and its correlation with land use pattern was not as strong as other factors.

\section{Projected land use change in 2020}

In this study, the land use in 2020 was simulated through scenario analysis using an MCE-CA-Markov model (shown in Table 4; Fig. 7). In scenario 1, water and builtup land were still the most dynamic land use type with 
Table 4 Simulated results of land use in 2020 under scenario 1 and scenario 2 in the Pengxi River basin

\begin{tabular}{|c|c|c|c|c|c|}
\hline \multirow[t]{2}{*}{ Scenario } & \multirow[t]{2}{*}{ Land use type } & \multicolumn{2}{|c|}{ Area $\left(\mathrm{km}^{2}\right)$} & \multirow{2}{*}{$\begin{array}{l}\text { Change range }\left(\mathrm{km}^{2}\right) \\
2010-2020\end{array}$} & \multirow{2}{*}{$\begin{array}{l}\text { Land use dynamic } \\
\text { index } K(\%) \\
2010-2020\end{array}$} \\
\hline & & 2010 & 2020 & & \\
\hline \multirow[t]{6}{*}{ Scenario 1} & Paddy field & 619.15 & 603.20 & -15.95 & -0.26 \\
\hline & Dry farming & 1492.93 & 1474.07 & -18.86 & -0.13 \\
\hline & Forest land & 1535.40 & 1521.13 & -14.27 & -0.09 \\
\hline & Grassland & 942.35 & 928.84 & -13.51 & -0.14 \\
\hline & waters & 63.01 & 104.39 & 41.38 & 6.57 \\
\hline & Built-up land & 23.87 & 45.08 & 21.21 & 8.89 \\
\hline \multirow[t]{6}{*}{ Scenario 2} & Paddy field & 619.15 & 604.67 & -14.48 & -0.23 \\
\hline & Dry farming & 1492.93 & 1480.95 & -11.98 & -0.08 \\
\hline & Forest land & 1535.40 & 1530.63 & -4.77 & -0.03 \\
\hline & Grassland & 942.35 & 931.87 & -10.48 & -0.11 \\
\hline & Water body & 63.01 & 67.20 & 4.19 & 0.66 \\
\hline & Built-up land & 23.87 & 61.39 & 37.52 & 15.72 \\
\hline
\end{tabular}

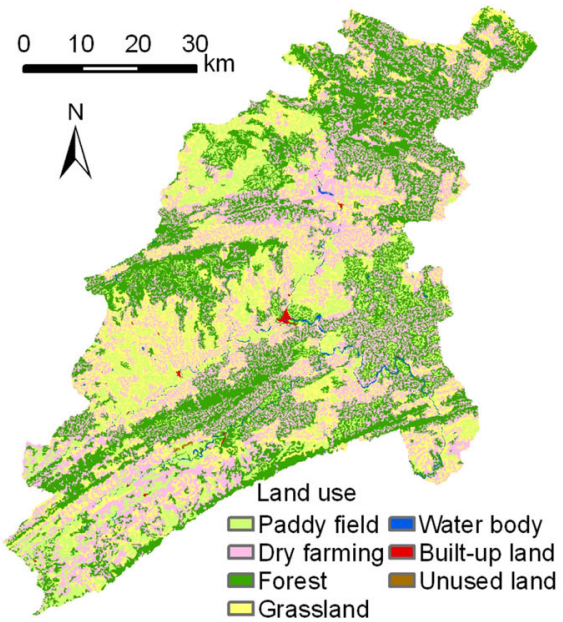

(a)

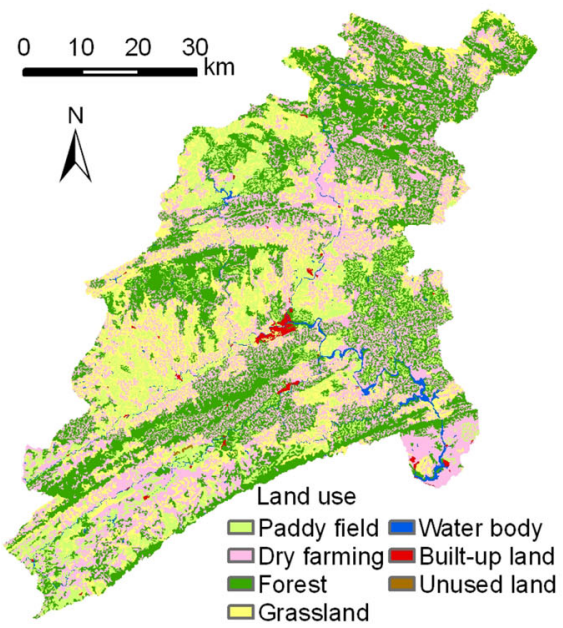

(d)

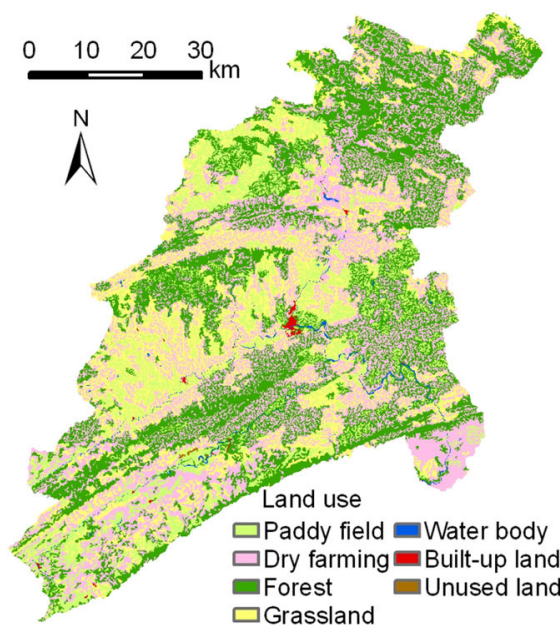

(b)

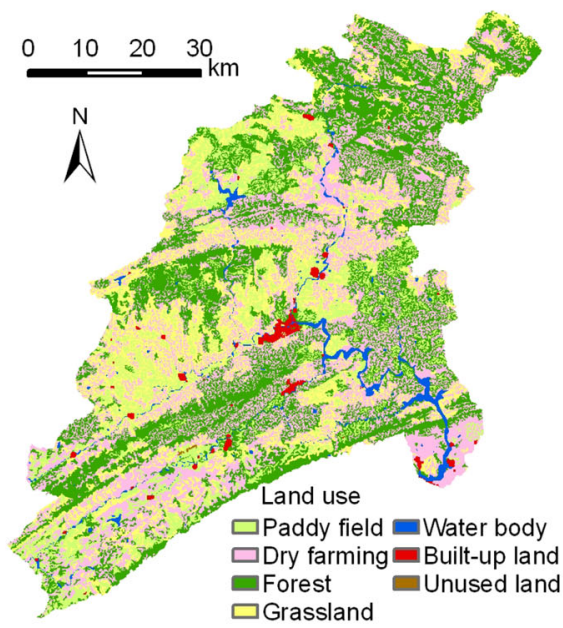

(e)

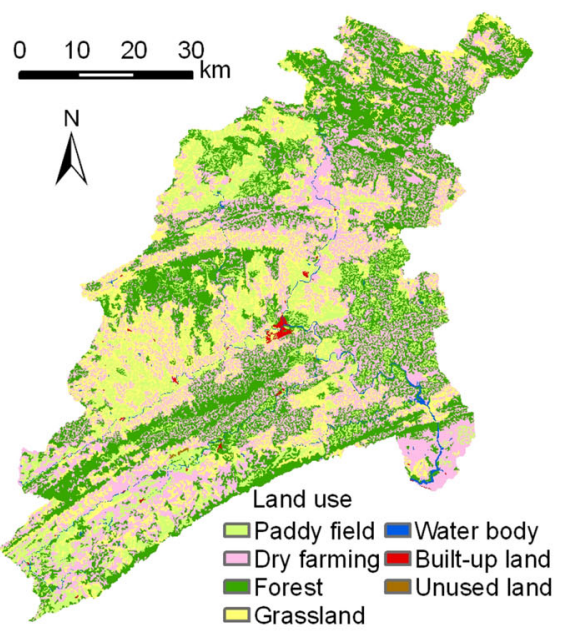

(c)

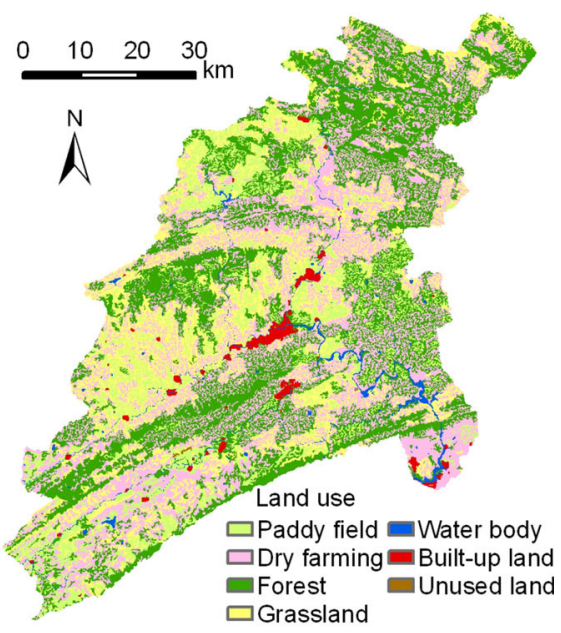

(f)

Fig. 7 Land use maps from 1995 to 2010 and simulated land use maps in 2020 in the Pengxi River basin. a 1995, b 2000, c 2005, d 2010, e 2020 under scenario 1 and $\mathbf{f} 2020$ under scenario 2 
Fig. 8 Simulated land use maps for typical area A and area B in 2020 under two different scenarios: a area A under scenario $1, \mathbf{b}$ area $\mathrm{A}$ under scenario 2, $\mathbf{c}$ area $\mathrm{B}$ under scenario 1 and $\mathbf{d}$ area $\mathrm{B}$ under scenario 2

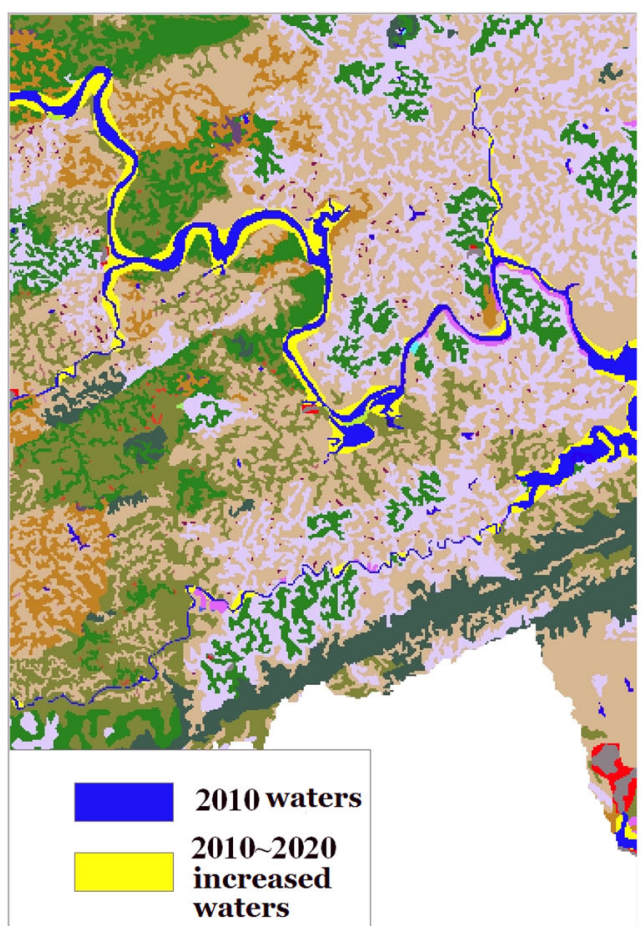

(a)

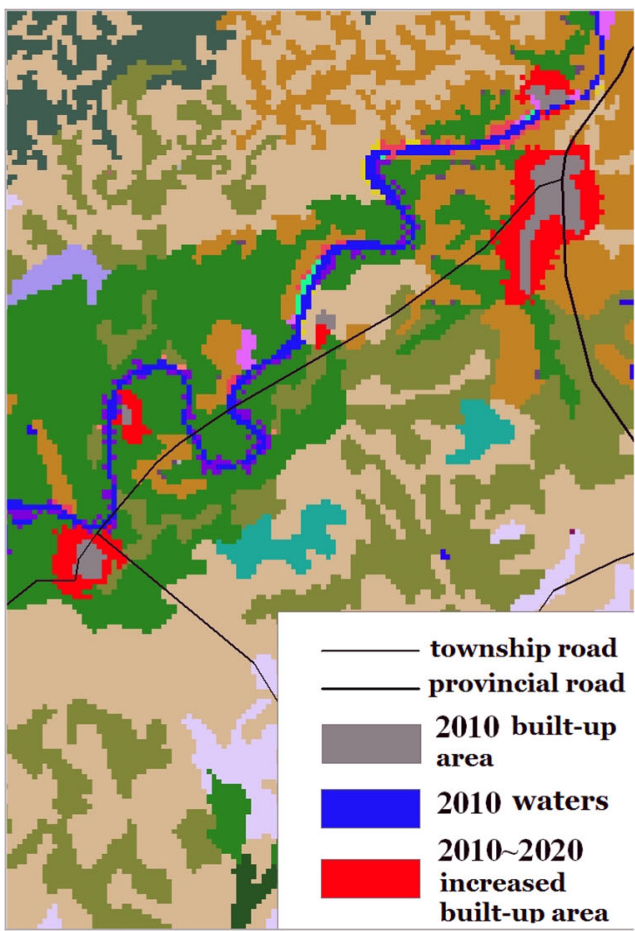

(c)

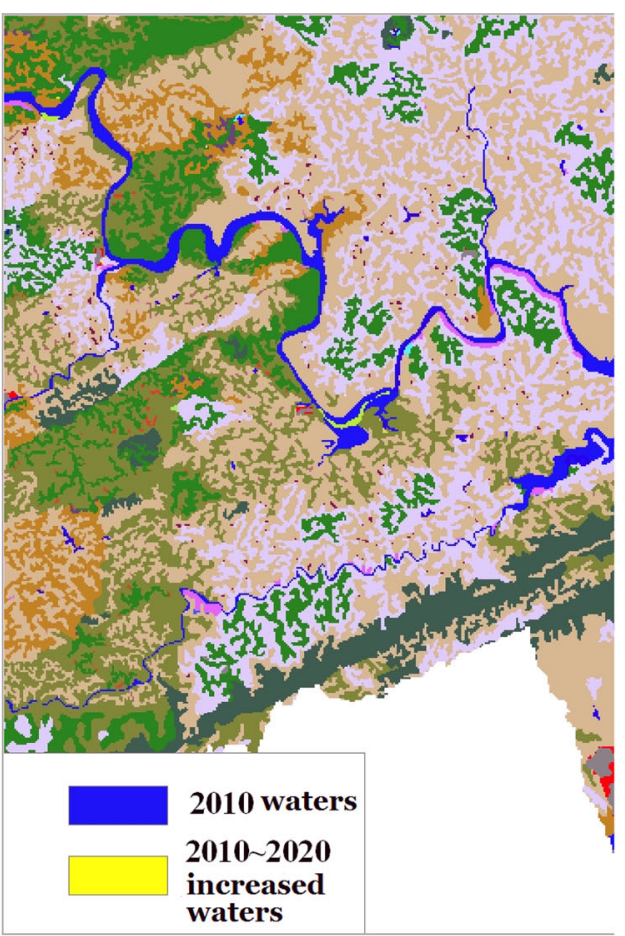

(b)

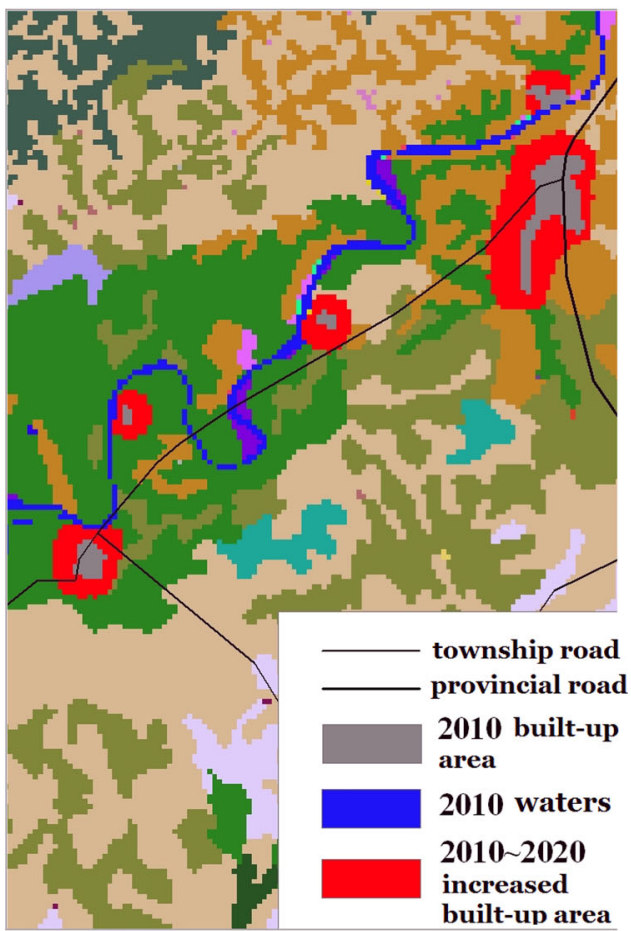

(d) increasing area in the prediction period, showing a change rate $(K)$ of 6.57 and $8.89 \%$ during 2010-2020, respectively. Other land uses continued to decrease and be transformed into these two types. In scenario 2, water remained stable in the prediction period, but built-up land was still highly dynamic, showing a change rate of 0.66 and $15.72 \%$ during 2010-2020, respectively. Other land uses were less dynamic compared with the results from scenario 1. In terms of spatial distribution, the expansion of built-up land area around five intended key industrial zones 
[Bai-He, Ping-Qiao, Zhao-Jia, Kai-Zhou Port and YunYang Industrial Zones (part A, B and C) in Fig. 1] was obvious.

From scenario 1, it was found that the extension of water bodies would probably continue for the next 10 years, which was obviously unreasonable. In scenario 2 , the situation of a basically completed TGR construction project was incorporated in the simulation. Therefore, the expansion of water area would be stabilized (see Fig. 8a, b in typical area A), and its encroachment on other types of land use would be weak in the future. Under the constraints of future reservoir protection policies and plans, land protection for specific land use types (e.g., fluctuation zones) and in specific areas (slope above $25^{\circ}$ ) was fulfilled. In relation to the facilitation of urban planning and economic development, the spatial distribution of built-up land was more concentrated and its expansion speed was faster than scenario 1 (see Fig. 8b, d in typical area B). By including these limitation terms in the analysis, the land use changes predicted by scenario 2 seemed to be more realistic.

\section{Conclusions}

The results of this study quantified the role of TGR construction in relation to land use change in the Pengxi River basin. Water bodies and built-up areas were the most dynamic land use types, corresponding to reservoir impoundment and population resettlement, with increasing areas of land transferred from other land use types. The spatial expansion characteristics in water area and built-up land revealed the process and influence of TGR construction. Geographical and environmental factors were still the controlling factors of regional land use patterns against the background of TGR construction. In relation to land use pattern in 2020, scenario 2, incorporating the perspectives of the future reservoir protection and development plans as well as the current construction progress of the TGR, was found to be reasonable and helpful for management.

The indirect influences of TGR construction on land use change after 2010 were also compared using the scenarios. After the construction project is finished, a new period of reservoir protection and sustainable use will begin. At this time, the indirect influence of reservoir construction will mainly be reflected through related policies or plans especially from the perspective of reservoir water conservation. This kind of influence could be regarded as a byproduct of big dam construction. From this point of view, future land use simulation and prediction must consider the indirect influence of reservoir construction. Otherwise, the prediction results cannot provide sound support for management decisions.
Acknowledgments The research was financially supported by National Science and Technology Major Project (No. 2012ZX07503002) and International Science and Technology Cooperation Program (No. 2007DFA90510) of China.

\section{References}

Ahearn DS, Sheibley RW, Dahlgren RA, Aderson M, Johnson J, Tate KW (2005) Land use and land cover influence on water quality in the last free-flowing river draining the western Sierra Nevada, California. J Hydrol 313:234-247

Al-Ahmadi K, See L, Heppenstall A, Hogg J (2009) Calibration of a fuzzy cellular automata model of urban dynamics in Saudi Arabia. Ecol Complex 6:80-101. doi:10.1016/j.ecocom.2008.09. 004

Austin NJ, Muller JP, Gong L, Zhang J (2013) A regional investigation of urban land-use change for potential landslide hazard assessment in the Three Gorges Reservoir Area, People's Republic of China: Zigui to Wanzhou. Int J Remote Sens 34(8):2983-3011. doi:10.1080/01431161.2012.744528

Barredo JI, Kasanko M, McCormick N, Lavalle C (2003) Modelling dynamic spatial processes: simulation of urban future scenarios through cellular automata. Landsc Urban Plan 64(3):145-160. www.elsevier.com/locate/landurbplan

Bell EJ (1974) Markov analysis of land use change: an application of stochastic processes to remotely sensed data. Socio Econ Plan Sci 8:311-316. doi:10.1016/0038-0121(74)90034-2

Bergmann A, Bi Y, Chen L et al (2012) The Yangtze-Hydro project: a Chinese-German environmental program. Environ Sci Pollut Res 19:1341-1344. doi:10.1007/s11356-011-0645-7

Cao Y, Zhou W, Wang J, Yuan C (2011) Spatial-temporal pattern and differences of land use changes in the Three Gorges Reservoir Area of China during 1975-2005. J Mt Sci 8(4):551-563. doi:10. 1007/s11629-011-2008-8

CDRI (2009) Implementation plan of comprehensive improvement of water environment in Pengxi River basin of Chongqing City. Chongqing Design and Research Institute of China Coal International Engineering Group, Chongqing (in Chinese)

Chongqing Bureau of Statistics (2012) Chongqing statistical yearbook 2012. China Statistics Press, Beijing

Comarazamy DE, González JE, Luvall JC, Rickman DL, Bornstein RD (2013) Climate impacts of land-cover and land-use changes in tropical islands under conditions of global climate change. J Clim 26(5):1535-1550. doi:10.1175/JCLI-D-12-00087.1

Cui XW, Zhang L, Zhu L, Song G, Wu BF (2012) Changes of landscape pattern and its characteristics in Kaixian county before and after impoundment of Three Gorges Dam Project. Trans CSAE 28(4):227-234. doi:10.3969/j.issn.1002-6819.2012.04. 038 (in Chinese)

EOTGPCC (2011) Overall plan for the follow-up work of the Three Gorges during 2011-2020. Executive Office of Three Gorges Project Construction Commission State Council of China, Beijing (in Chinese)

Fearnside PM (2015) Environmental and social impacts of hydroelectric dams in Brazilian Amazonia: implications for the aluminum industry. World Dev 77:48-65. doi:10.1016/j.world dev.2015.08.015

Fu XT, Wang SL, Zhang HZ, Peng YB, Zhou SL, Yin ZW, Meng ZH (2013) Emigration of hydropower projects in Hubei Province. Yangtze river press, Wuhan (in Chinese)

Gómez-Delgado M, Tarantola S (2007) GLOBAL sensitivity analysis, GIS and multi-criteria evaluation for a sustainable planning of ahazardous waste disposal site in Spain. Int J Geogr Inf Sci 20:449-466. doi:10.1080/13658810600607709 
Guan DJ, Li HF, Inohae T, Su WC, Nagaie T, Hokao K (2011) Modeling urban land use change by the integration of cellular automaton and Markov model. Ecol Model 222:3761-3772. doi:10.1016/j.ecolmodel.2011.09.009

He L, King L, Jiang T (2003) On the land use in Three Gorges Reservoir area. J Geogr Sci 13(4):416-422

Holbach A, Wang L, Chen H, Hu W, Schleicher N, Zheng B, Norra S (2013) Water mass interaction in the confluence zone of the Daning River and the Yangtze River-a driving force for algal growth in the Three Gorges Reservoir. Environ Sci Pollut Res 20:7027-7037. doi:10.1007/s11356-012-1373-3

Huang Z, Zhou W, Zhou J, Zhu M (2006) Land Use of the Three Gorges Reservoir area and the effect on its landscape pattern in the recent 50 Years. Wuhan Univ J Nat Sci 11:910-914

Jackson S, Sleigh A (2000) Resettlement for China's Three Gorges Dam: socio-economic impact and institutional tensions. Communist Post-communist Stud 33:223-241. www.elsevier.com/ locate/postcomstud

Jiang H, Qiang M, Peng L (2016) Finding academic concerns of the Three Gorges Project based on a topic modeling approach. Ecol Indic 60:693-701. doi:10.1016/j.ecolind.2015.08.007

Kamusoko C, Aniya M, Adi B, Manjoro M (2009) Rural sustainability under threat in Zimbabwe: simulation of future land use/cover changes in the Bindura district based on the Markovcellular automata model. Appl Geogr 29:435-447. doi:10.1016/j. apgeog.2008.10.002

Li H, Waley P, Rees P (2001) Reservoir resettlement in China: past experience and the Three Gorges Dam. Geogr J 167:195-212. http://www.jstor.org/stable/3060588

Li YB, Shao J-A, Li YC (2010) The status and prospect of land use/land cover changes in Three Gorges Reservoir Area. J Chongqing Normal University (Nat Sci) 27(2):31-35. doi:10. 3969/J.ISSN.1672-6693.2010.02.009 (in Chinese)

Li H, Ma ZZ, Xiang YF (2015) Study on spatiotemporal characteristics of land use change of wanzhou district in the Three Gorges Reservoir Area. Res Soil Water Conserv 22(2):84-89. doi:10. 13869/j.cnki.rswc.2015.02.018 (in Chinese)

Liu J, Liu M, Tian H, Zhuang D, Zhang Z, Zhang W, Tang X, Deng X (2005) Spatial and temporal patterns of China's cropland during 1990-2000: an analysis based on Landsat TM data. Remote Sens Environ 98:442-456. doi:10.1016/j.rse.2005.08.012

Mahmoud SH, Alazba AA (2015) Hydrological response to land cover changes and human activities in arid regions using a geographic information system and remote sensing. PLoS ONE 10(4):e0125805. doi:10.1371/journal.pone.0125805

MEP (2012) National key watershed water pollution prevention plan for 2011-2015. Ministry of Environmental Protection of China, Beijing (in Chinese)

Mondal P, Southworth J (2010) Evaluation of conservation interventions using a cellular automata-Markov model. Forest Ecol Manag 260:1716-1725. doi:10.1016/j.foreco.2010.08.017

Morgan TKKB, Sardelic DN, Waretini AF (2012) The Three Gorges Project : how sustainable. J Hydro 460-461:1-12. doi:10.1016/j. jhydrol.2012.05.008

Nguyen TT, Verdoodt A, Tran VY, Delbecque N, Tran TC, Ranst EV (2015) Design of a GIS and multi-criteria based land evaluation procedure for sustainable land-use planning at the regional level. Agr Ecosyst Environ 200:1-11. doi:10.1016/j. agee.2014.10.015

Nilsson C, Reidy CA, Dynesius M, Revenga C (2005) Fragmentation and flow regulation of the world's large river systems. Science 308:405-408. doi:10.1126/science.1107887

Orr S, Pittock J, Chapagain A (2012) Dams on the Mrkong River: lost fish protein and the implication for land and water resources. Global Environ Change 22:925-932. doi:10.1016/j.gloenvcha. 2012.06.002
Osborne LL, Wiley MJ (1988) Empirical relationships between land use/cover and stream water quality in an agricultural watershed. J Environ Manage 26:9-27

Peng C, Zhang L, Qin H, Li D (2014) Revegetation in the water level fluctuation zone of a reservoir: an ideal measure to reduce the input of nutrients and sediment. Ecol Eng 71:574-577. doi:10. 1016/j.ecoleng.2014.07.078

Pontius Jr RG (2000) Quantification error versus location error in comparison of categorical maps. Photogramm Eng Rem Sens 66:1011-1016. http://eserv.asprs.org/PERS/2000journal/aug/2000 aug_1011-1016.pdf

Pontius Jr RG (2002) Statistical methods to partition effects of quantity and location during comparison of categorical maps at multiple resolutions. Photogramm Eng Rem Sens 68:1041-1049. http://eserv.asprs.org/PERS/2002journal/oct/2002_oct_1041-1049. pdf

Sang LL, Zhang C, Yang JY, Zhu DH, Yun WJ (2011) Simulation of land use spatial pattern of towns and villages based on CAMarkov model. Math Comput Model 54:938-943. doi:10.1016/j. mcm.2010.11.019

Sarwar J (1986) The determination of stability and similarity of Markovian land use change processes: a theoretical and empirical analysis. Socio Econ Plan Sci 20:243-251. doi:10.1016/ 0038-0121(86)90016-9

Schönbrodt-Stitt S, Behrens T, Schmidt K, Shi X, Scholten T (2013a) Degradation of cultivated bench terraces in the Three Gorges Area: field mapping and data mining. Ecol Indic 34:478-493. doi:10.1016/j.ecolind.2013.06.010

Schönbrodt-Stitt S, Bosch A, Behrens T, Hartmann H, Shi X, Scholten T (2013b) Approximation and spatial regionalization of rainfall erosivity based on sparse data in a mountainous catchment of the Yangtze River in Central China. Environ Sci Pollut Res 20(10):6917-6933. doi:10.1007/s11356-012-1441-8

Seeber C, Hartmann H, Xiang W, King L (2010) Land use change and causes in the Xiangxi catchment, Three Gorges area derived from multispectral data. J Earth Sci 21(6):846-855. doi:10.1007/ s12583-010-0136-7

Shao HY, Xian W, Yang WN, Zhou WC (2008) Land use/cover change during lately 50 years in Three Gorges Reservoir Area. Chin J Appl Ecol 19(2):453-458 (in Chinese)

Shao J-A, Zhang SC, Wei CF (2013) Remote sensing analysis of land use change in the Three Gorges Reservoir area, based on the construction phase of large-scale water conservancy project. Geogr Res 32(12):2089-2203. doi:10.11821/dlyj201312002 (in Chinese)

Shen G, Xie Z (2004) Three Gorges project: chance and challenge. Science 304:681

Shen Z, Chen L, Hong Q, Qiu J, Xie H, Liu R (2013) Assessment of nitrogen and phosphorus loads and causal factors from different land use and soil types in the Three Gorges Reservoir Area. Sci Total Environ 454-455:383-392. doi:10.1016/j.scitotenv.2013. 03.036

Stone R (2008) Three Gorges Dam: into the unknown. Science 321:628-632

Stone R (2011) The legacy of Three gorges dam. Science 333:817

Strehmel A, Schönbrodt-Stitt S, Buzzo G, Dumperth C, Stumpf F, Zimmermann K, Bieger K, Behrens T, Schmidt K, Bi R, Rohn J, Hill J, Udelhoven T, Xiang W, Shi X, Cai Q, Jiang T, Fohrer N, Scholten T (2015) Assessment of Geo-Hazards in a Rapidly Changing Landscape: the Three Gorges Reservoir Region in China. Environ Earth Sci 74:1-22. doi:10.1007/s12665-0154503-7

Sun DF, Li H, Lin P (2003) Monitoring land use and landscape changes caused by migrant resettlement with remote sensing in Region of Three Gorges of Yangtze River. Trans CSAE 19(5):218-224 
Tullos D (2009) Assessing the influence of environmental impact assessments on science and policy: an analysis of the Three Gorges Project. J Environ Manage 90:S208-S223. doi:10.1016/j. jenvman.2008.07.031

Wang G, Song J, Xue BL, Xu X, Otsuki K (2012) Land Use and Land Cover Change of Hulun Lake Nature Reserve in Inner Mongolia, China: a modeling analysis. J Fac Agr Kyushu Univ 57(1):219-225

Wang G, Yang H, Wang L et al (2014a) Using the SWAT model to assess impacts of land use changes on runoff generation in headwaters. Hydrol Process 28:1032-1042. doi:10.1002/hyp.9645

Wang L, Chen C, Zou R, Du J (2014b) Surface gravity and deformation effects of water storage changes in China's Three Gorges Reservoir constrained by modeled results and in situ measurements. J Appl Geophys 108:25-34. doi:10.1016/j. jappgeo.2014.06.007

Xiao JY, Shen YJ, Ge JF, Tateishi R, Tang CY, Liang YQ, Huang ZY (2006) Evaluating urban expansion and land use change in Shijiazhuang, China, by using GIS and remote sensing. Landsc Urban Plan 75:69-80. doi:10.1016/j.landurbplan.2004.12.005

Xu QG, Liu HL, Xi BD, Shen ZY, Wei ZM (2007) Land use and landscape pattern change in Three Georges Reservoir area. Environ Sci Technol 30(12):83-86 (in Chinese)

Zhang Q, Lou Z (2011) The environmental changes and mitigation actions in the Three Gorges Reservoir region, China. Environ Sci Policy 14(8):1132-1138. doi:10.1016/j.envsci.2011.07.008
Zhang L, Dong LX, Wu BF, Zhou WC (2007) Land cover change before and after the construction of Three Gorges Reservoir within 10 years. Resour Environ Yangtze Basin 16(1):107-112 (in Chinese)

Zhang J, Liu Z, Sun X (2009) Changing landscape in the Three Gorges Reservoir Area of Yangtze River from 1977 to 2005: land use/land cover, vegetation cover changes estimated using multi-source satellite data. Int J Appl Earth Obs 11:403-412. doi:10.1016/j.jag.2009.07.004

Zhang Q, Ban YF, Liu JY, Hu YF (2011) Simulation and analysis of urban growth scenarios for the Greater Shanghai Area, China. Comput Environ Urban Syst 35:126-139. doi:10.1016/j.compen vurbsys.2010.12.002

Zhao Q, Liu S, Deng L et al (2013) Determining the influencing distance of dam construction and reservoir impoundment on land use: a case study of Manwan Dam, Lancang River. Ecol Eng 53:235-242. doi:10.1016/j.ecoleng.2012.12.050

Zhao Y, Zheng B, Wang L, Qin Y, Li H, Cao W (2015) Characterization of mixing processes in the confluence zone between the Three Gorges Reservoir mainstream and the Daning River using stable isotope analysis. Environ Sci Technol. doi:10. 1021/acs.est.5b01132

Zhu HY, Li XB (2003) Discussion on the index method of regional land use change. Acta Geogr Sin 58:643-650 (in Chinese) 